\title{
Producing adornment: Evidence of different levels of expertise in the production of obsidian items of adornment at two late Neolithic communities in northern Mesopotamia
}

\author{
Elizabeth Healey, Stuart Campbell \\ School of Arts, Languages and Cultures, University of Manchester, UK. \\ Email: Healey: elizabeth.healey@manchester.ac.uk; Campbell: stuart.campbell@manchester.ac.uk
}

\begin{abstract}
:
In the Near East obsidian is of particular interest to archaeologists because it is an exotic material and best known for is use in tool manufacture, but it is also occasionally used to make items of personal adornment. Some of these items are very highly finished, while others appear much more rudimentary though it is by no means obvious why this should be. Here we will review such artefacts at two contemporary late Neolithic communities, Domuztepe in SE Anatolia and Tell Arpachiyah in northern Iraq. Both have seemingly unusually high numbers of such objects as well as evidence for obsidian tool production on site. At Domuztepe some objects are highly finished while others appear much more ad hoc. At Arpachiyah on the other hand, the objects appear very similar to each other so as to seem standardised or at least the product of a single workshop. Our main aim in this paper is to try to unravel the evidence needed to determine whether they were produced on site, or whether they were acquired as finished objects (or both).
\end{abstract}

Keywords: obsidian; obsidian as personal adornment; Domuztepe; Arpachiyah

\section{Introduction}

Obsidian is an exotic raw material at most sites in the Near East and best known for its use, alongside flint, as a material from which to make tools. Some excavations have also produced items of personal adornment, mirrors and vessels made of obsidian. Some of these objects are very highly finished while others appear more rudimentary. The exotic and aesthetic nature of obsidian along with this unusual way of using it (and in a way that flint was not ${ }^{1}$ ) suggests that as a raw material, it may have had a special place in people's world views (Healey 2013). Since items of jewellery and personal adornment are also often considered to be markers of different identities and social status (see for example, Costin et al. 1998, White 2007: 287; Wright \& Garrard 2003), the additional factor of the choice of obsidian as a raw material may have accorded them additional meaning. It follows from this

Published by the School of History, Classics and Archaeology, University of Edinburgh ISSN: 2055-0472. URL: http://journals.ed.ac.uk/lithicstudies/

This work is licensed under a Creative Commons Attribution 2.5 UK: Scotland License. 
that the places and processes of manufacture might provide insights into the structure and allegiances of the communities that made and possessed such objects.

Hitherto the focus of study has tended to be on obsidian as a raw material, especially its origins and distribution (Cauvin et al. 1998) and more recently on technological characteristics (Binder 2008; Pelegrin 2012). Little attention has been paid to the nonutilitarian items, let alone to their manufacture or how they were used (see Wright \& Garrard 2003 for a similar situation involving other materials). Here we will attempt to contextualize such objects at two broadly contemporary sixth millennium cal. BC communities of rather different type, Domuztepe in south-east Anatolia and Tell Arpachiyah in northern Iraq (Figure 1). Both sites have unusually high numbers of ground and polished items of obsidian as well as evidence of obsidian working and tool production. Wider and in-depth studies of the obsidian and other lithics from both sites is underway elsewhere (Healey in preparation; Campbell \& Healey in preparation) but the particular question we want to address here is whether the non-tool items of obsidian were made within the communities and whether specialist craftspeople were involved or whether they were acquired as finished objects (or both).

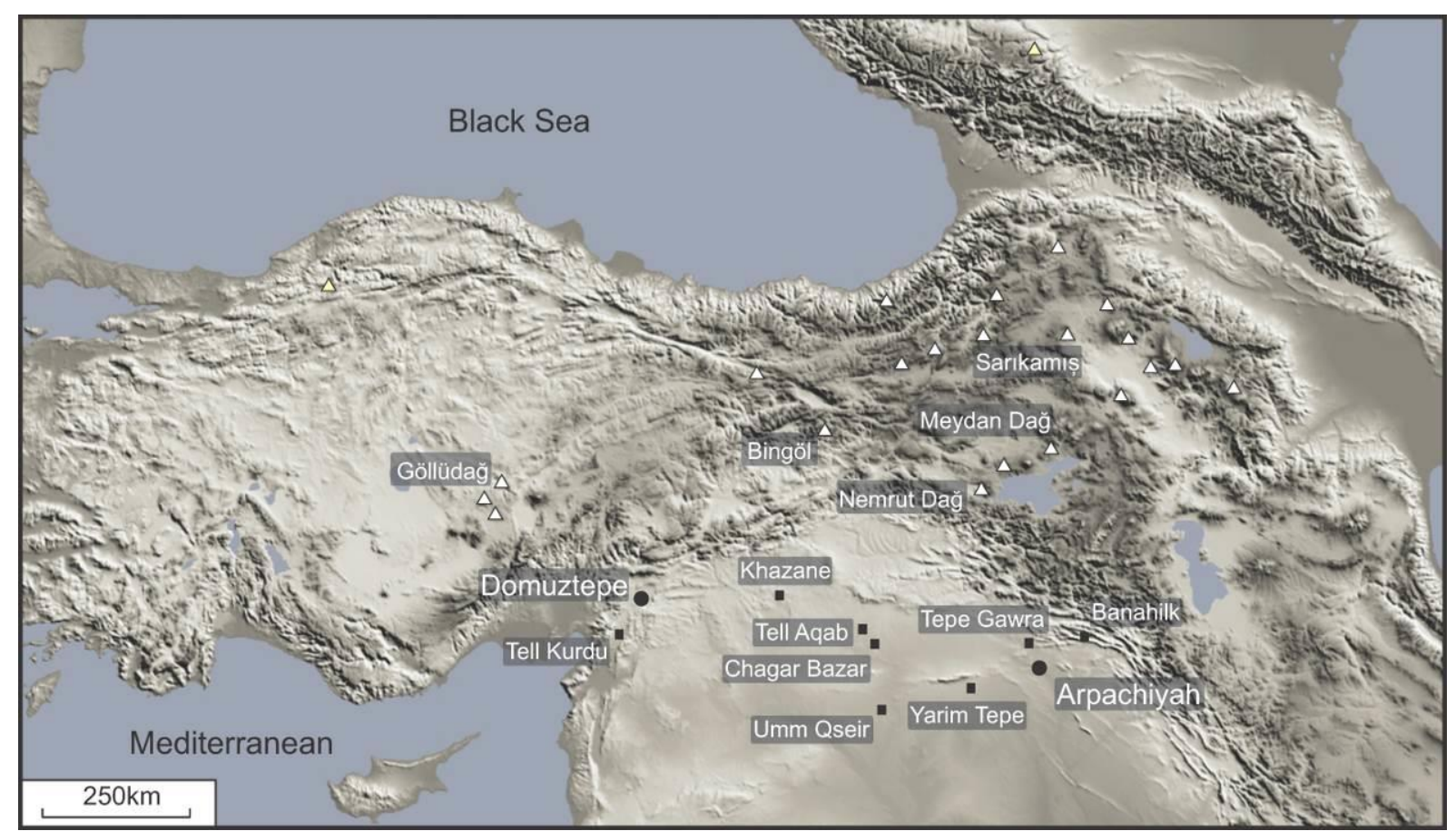

Figure 1. Map showing the location of Arpachiyah and Domuztepe (circles) and other sites (squares) mentioned in the text in relation to obsidian sources (open triangles) (Source Stuart Campbell).

\section{Obsidian use at Domuztepe}

Domuztepe is a large site (Figure 2) occupied from the early ceramic Neolithic through to the late Neolithic (c. 6800-5450 cal. BC) and then again in the first millennium AD.

The main focus of the excavation has been on the Halaf period (c.6100-5450 cal. BC). In this period settlement covered some 20 ha. It may have comprised a number of loosely knit communities with some evidence for the demarcation of space albeit with limited evidence of hierarchy. Identities and social roles may have been marked by or reflected in the material culture including elaborately painted ceramics, figurines, stone bowls, stamp seals, beads and other jewellery made of stone, shells and bone (Campbell \& Fletcher 2013: 42-43). The main raw material used for chipped stone tool manufacture is locally obtainable flint which was regularly worked within different contexts at Domuztepe; there is also some evidence for the 
occasional choice and elaborate working of attractive and possibly non-local flints. Other non-local raw materials include a range of obsidians, from various geographically widely separated sources between $250 \mathrm{~km}$ and $900 \mathrm{~km}$ away. Obsidian artefacts from different sources account for about $9-20 \%$ of the tool kit depending on context. This obsidian component numbers around 8000 artefacts and comprises cores, flakes, blades and some retouched pieces as well as over 190 non-tool items including beads, links, pendants, mirrors, vessels and other items which have been finished by grinding and polishing; a selection is illustrated in Figure 3.

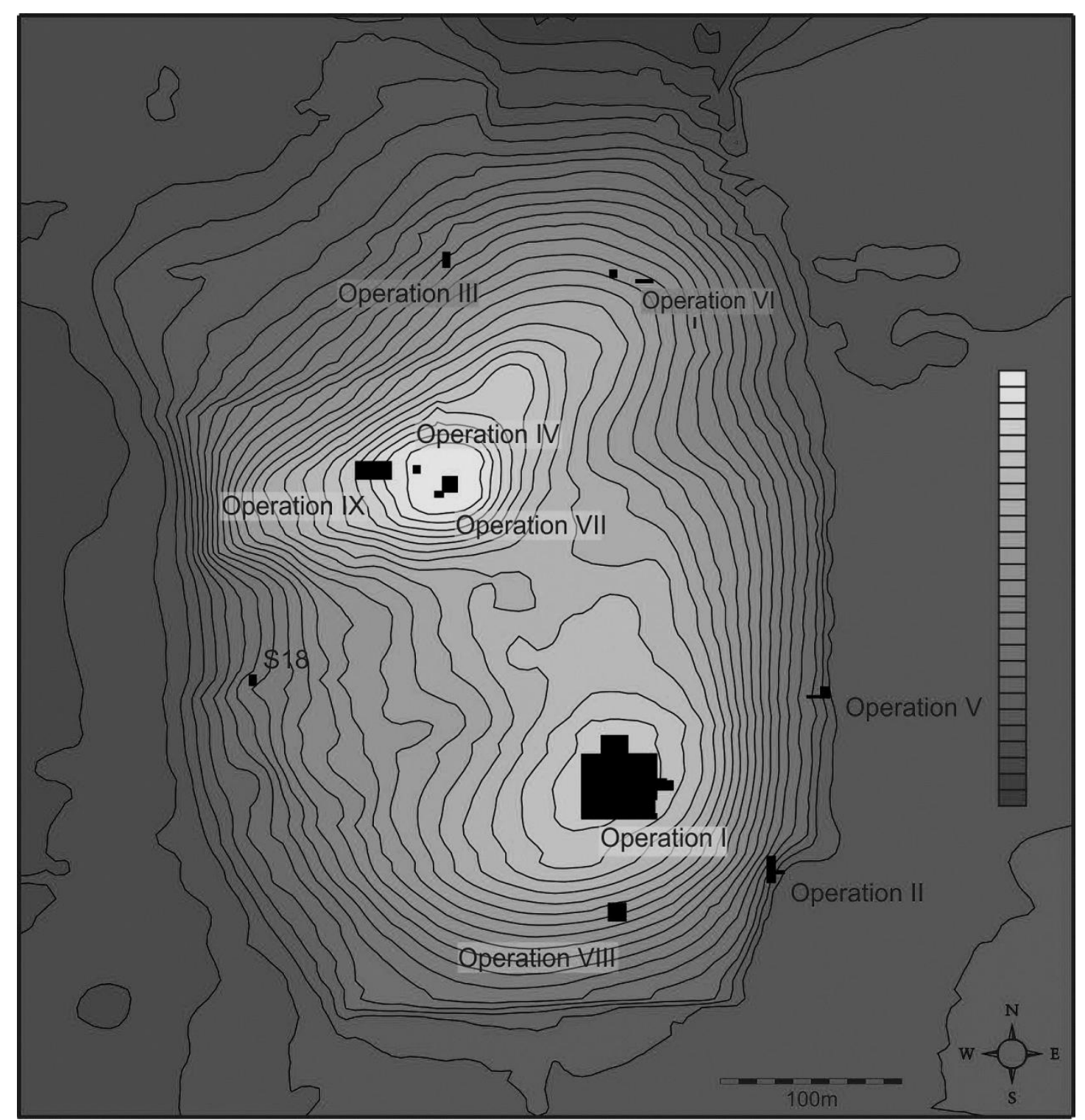

Figure 2. Contour plan of Domuztepe, showing excavated areas (source Stuart Campbell)

Most come from late Halaf contexts but earlier examples are also present (Healey 2013: Table 22.1). Some of these items are much more elaborate than others both in terms of their finish and in their concept. Less elaborate forms include pendants, no. 3, made on a flake shaped by rudimentary grinding (see also Healey 2013: Fig. 22.4, nos. 2 and 3). These are of a very different ilk from the highly polished objects such as Figure 3, nos. 1, 2, 4, 6 and 7. Some idea of the significance and perhaps value of such items is suggested by their repair after breakage. For example one small, highly finished, incised pendant, dt3859, was reperforated and reshaped (Healey 2013: Fig. 22.4, no. 6). 


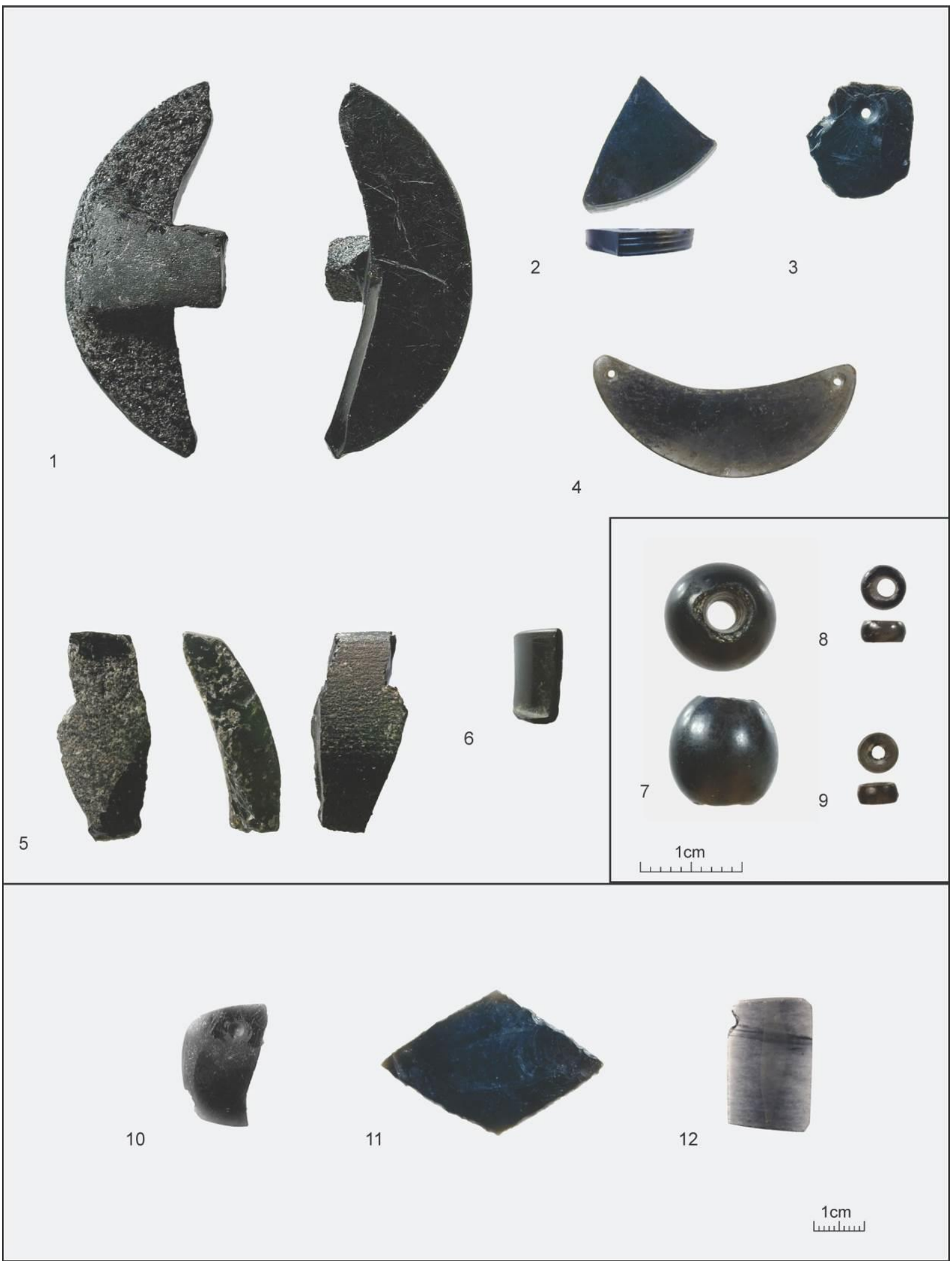

Figure 3. A selection of ground and polished objects from Domuztepe: 1. Mirror with strap handle, dt3494; 2. Highly polished disc or mirror with concentric grooves around the edges, dt427;3 Pendant, dt2141, with minimal grinding and break on perforation; 4 Crescentic link, dt1069; 5. Vessel fragment, dt2625, pecked and ground but not polished; 6. Rim fragment of highly polished vessel, dt275; 7-9. Beads, dt1107, dt2832 and dt2227; 10-12: Unfinished obsidian items, dt6973, dt354 and dt7164 (photographs by Stuart Campbell). 


\subsection{Unfinished items and possible bead production area}

Unfinished objects include a part-drilled link, Figure 3, no. 12, from a ceramic Neolithic context, and other partly drilled pieces, e.g., no. 10 from a later context; there is also a blade segment, no. 11, chipped into a lozenge-shape but not ground, and some rectangular pieces. Two blades also show incipient grinding which appears to have been deliberate, but they are not otherwise worked. In addition a number of small discoidal and rectangular objects, mainly of obsidian but also other raw materials, have been interpreted as bead blanks (see also Belcher 2011). These were found concentrated in a small area of a partially burnt complex of structures and activity areas which preserved quantities of in situ artefacts including ceramics, flint and obsidian. Apart from a number of drills (yet to be fully analysed, though there are none as obviously worn as those from Mezraa Teleilat (Coşkunsu 2008)), no tools (such as abraders, grinding stones, polishers) that could be specifically related to the manufacture of the beads have been identified.

In all 27 obsidian blanks or pre-forms of three different types were found in a restricted part of this area. They include nine disc-like pieces (Figure 4, nos. 6-8) which have been shaped by chipping around the edges, presumably blanks or preforms for barrel or biconical beads prior to grinding and perforation. The blanks measure between 7 and $10.7 \mathrm{~mm}$ in diameter and 4 to $7.3 \mathrm{~mm}$ in thickness (Figure 5). The size range of many of the finished obsidian beads is compatible with blanks of this size: the more robust finished beads (Figure 3 , no. 7) measure between $5.2 \mathrm{~mm}$ and $10 \mathrm{~mm}$ in diameter and $5 \mathrm{~mm}$ and $10 \mathrm{~mm}$ in thickness (Figure 5 top). Similar pieces in other raw materials were also recovered in this area and include a small unperforated sub-discoidal object of translucent green amorphous silica (Belcher 2011: Fig. 3).

The other two types of pre-forms (all obsidian) are thinner. One type is rectangular in shape and the other square to sub-discoidal (e.g., Figure 4, nos. 1-3, 9 and 10). The rectangular examples measure between 14 and $39 \mathrm{~mm}$ in length, the majority being under 20 $\mathrm{mm}$. They are made on blades, some of which have incipient grinding on their surfaces. The square examples, which are ground on both surfaces, are about 4.9 to $7.5 \mathrm{~mm}$ square and under $3 \mathrm{~mm}$ in thickness (Figure 5 bottom). It is possible that they are blanks for minute disc beads like those in Figure 3, nos. 9 and 10 (see also Healey 2013, Fig. 22.3, nos. 8-11), which often measure less than $4 \mathrm{~mm}$ in diameter and $1.6 \mathrm{~mm}$ in thickness.

There is also a small, partly ground tear-drop flake of obsidian (possibly an unfinished pendant), and a tranchet object with ground sides (Figure 4, nos. 4 and 5); the tranchet object seems to have been re-made from a larger object and is made of a different obsidian from the other blanks. A flake apparently from a ground and polished object and a fragmentary 'mirror', was also found in the same area as the bead blanks.

These items were associated with a considerable amount of obsidian and flint debitage and retouched pieces, suggesting that it was a chipped stone working area. Obsidian of various colours and types was present in this assemblage but the blanks were all made of transparent grey or grey-brown obsidian and it was also noted that this type of obsidian predominated in the contexts in which the bead blanks were found. In the rest of this complex, green obsidian is dominant. We were able to determine through pXRF analysis that seven of the blanks, the mirror fragment and the tear drop were made of obsidian which originated from Göllüdağ but that one was made of obsidian from Sarıkamış (Lehner et al. in preparation; Frahm et al. in preparation); both types of obsidian were also present amongst the debitage though relative proportions have not yet been determined.

On the basis of the above, we tentatively conclude that here we have the truncated remnants of an area where the preliminary stages of bead manufacture and perhaps other items was undertaken using specific types of obsidian and other raw materials alongside and 
perhaps as part of tool production (compare with the situation at Çatalhöyük described by Bains et al. 2013: 343). This was on a small scale, probably at household level (for examples see Costin 1991; Belcher 2011), akin to what Hirth describes as diversified household manufacture (Hirth 2009).

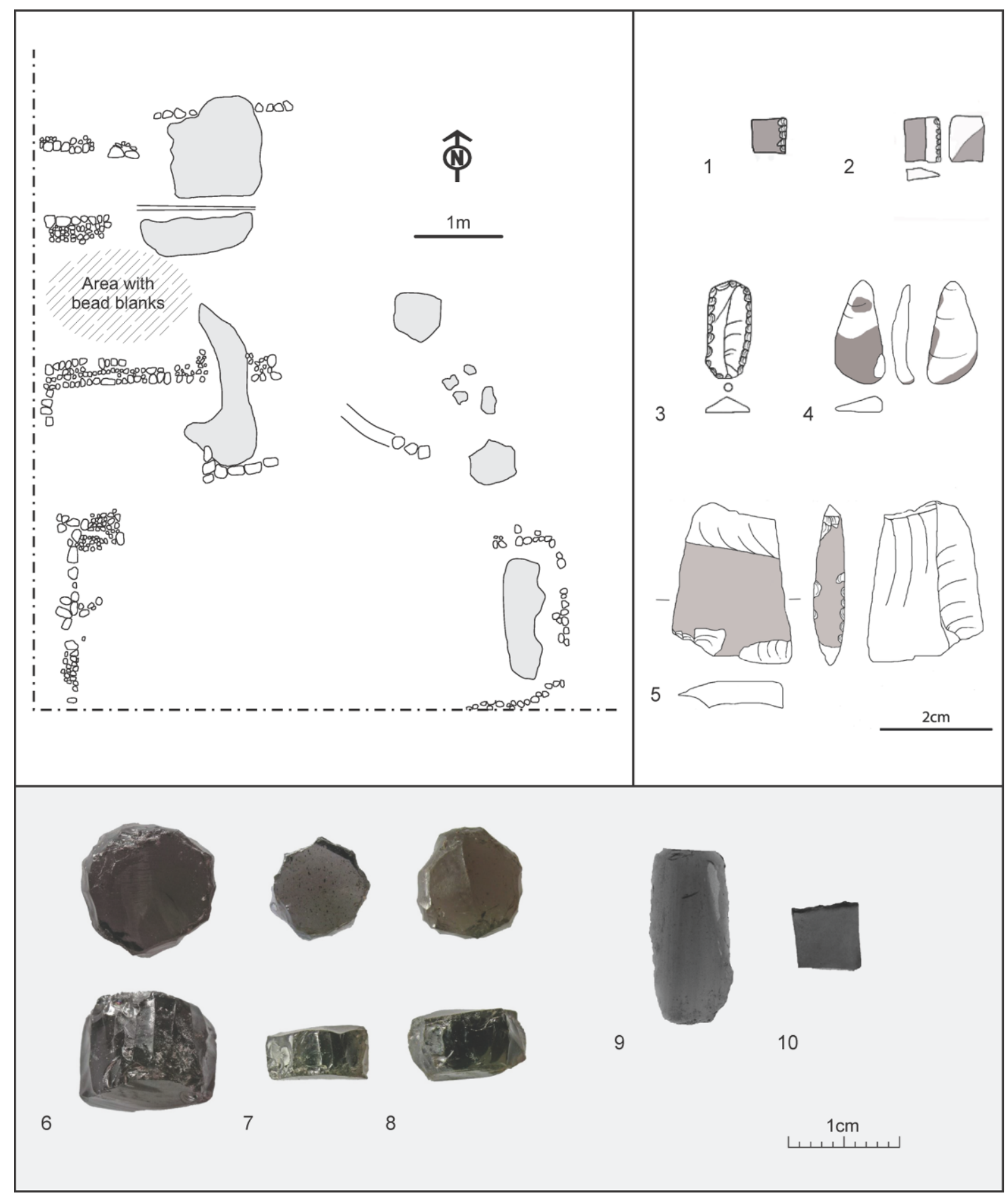

Figure 4. Upper left: Plan of activity areas around the Burnt Structure in Operation I at Domuztepe showing location of possible bead blanks. Right and lower: Square and rectangular blanks (nos. 1-3: L3919/10, L3959 and L4044). Incomplete pendant (no.4: dt4948). Incomplete tranchet (no. 5). Examples of discoidal bead blanks (nos. 6-8: dt4774, dt4595 and dt4835) and rectangular and square pieces (nos. 9 and 10: L3919-9 and L3919-10); L3919-10 is ground on its dorsal surface (Source, Stuart Campbell and Elizabeth Healey) 

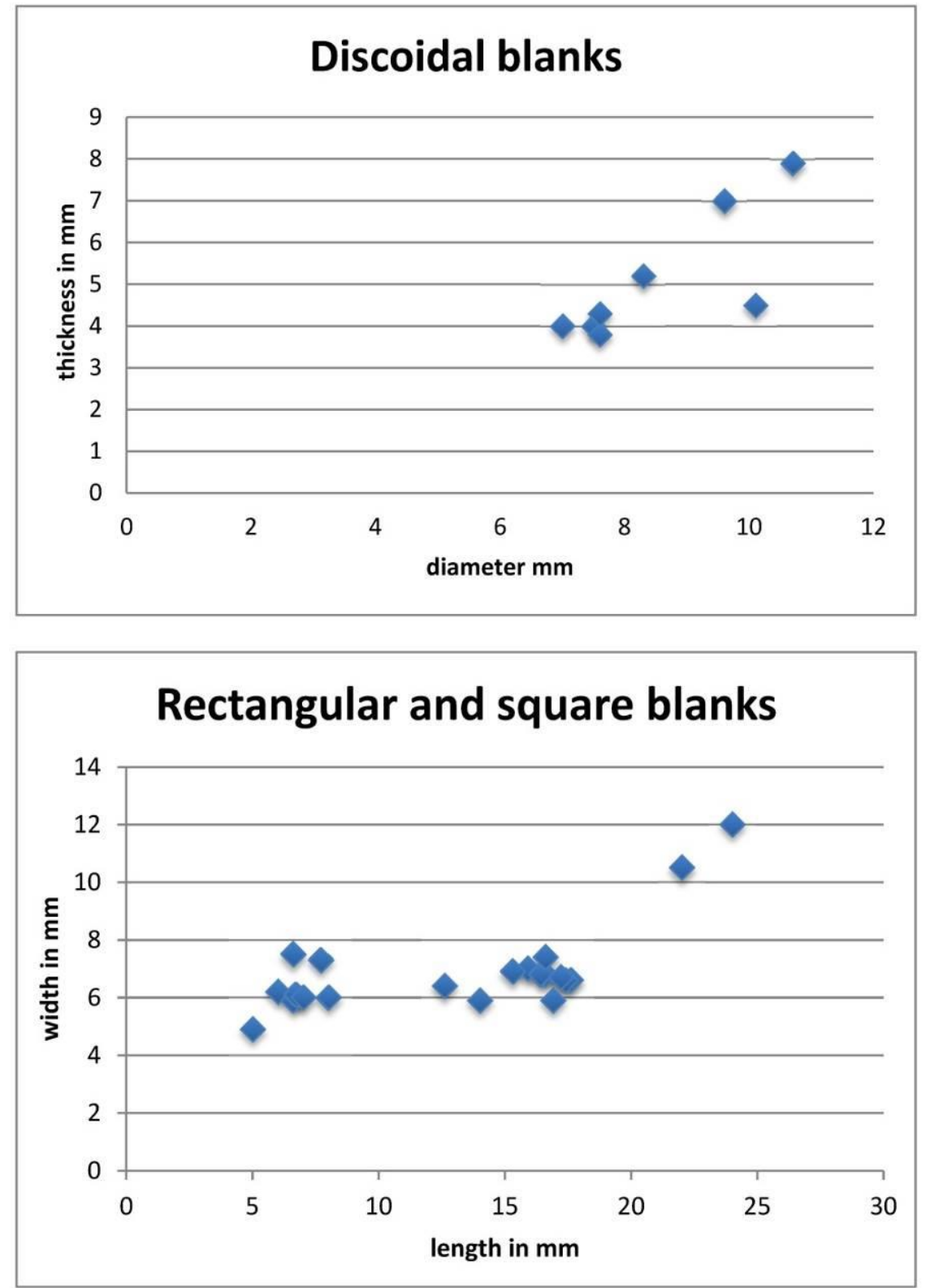

Figure 5. Chart showing dimensions of possible blanks from the Burnt Structure at Domuztepe (source Elizabeth Healey).

It is tempting to see the more rudimentarily produced pieces such as simple pendants and some of the beads, for example Figure 3, no. 3, 8-10, as products of similar production systems. The more elaborately finished obsidian objects such as some of the mirrors and most of the vessels suggest that they were deliberately designed and executed by experts either at Domuztepe or perhaps elsewhere.

\section{Obsidian use in the Burnt House at Tell Arpachiyah}

Arpachiyah, in contrast to Domuztepe, is a small tell with its main occupation from c. 6000 to $5000 \mathrm{cal}$. BC. Most of our best quality information comes from the building known as the 'Burnt House' which is dated to the mid sixth millennium cal. BC (i.e. the late Halaf) and is broadly contemporary with the late Halaf levels at Domuztepe. The Burnt House is a rare and unusual context interpreted in various ways, including as a centralizing institution and redistribution centre (Campbell 2000; Campbell and Fletcher 2013: 43). 
In it (and more precisely in the Long Room and the Full Room, Figure 6) were found some highly decorated ceramics, stamp seals, stone vessels, including one made of obsidian, figurines, a necklace made up of six obsidian lozenge-shaped links, cowrie shells and stone pendant and a clay bead, 36 rectangular links made of obsidian and a considerable amount of flint and obsidian tools and debitage (Figures 7-9) (Campbell 2000; Healey 2000). So many in fact that when excavated in 1933 the excavator, Sir Max Mallowan, described it in his notes as an obsidian workers dwelling (Mallowan nd: 245) and only later said "This house, which alike by its situation and size was clearly the property of one of the headmen of the village, proved to have been the workshop of a potter and a maker of stone vases and of flint and obsidian tools" (Mallowan \& Rose 1935: 16). He describes the flint and obsidian tools as "lying in confusion in a single room" and adds "there were in addition thousands of cores and chips characteristic of the debris in a stone-carver's shop" (Mallowan \& Rose 1935: 17, 103). The objects, though, were on charred wood, possibly a shelf or table, at the edge of a room suggesting deliberate placement (Mallowan \& Rose 1935: 17, 97). The necklace was seemingly found in the arrangement shown by Mallowan \& Rose (1935: 17, Pl. XI), however it has gone through various slightly different arrangements since then (Figure 7). The rectangular links (Figure 8), he suggested, adorned a helmet or similar object (Mallowan \& Rose 1935: 97). The other flint and obsidian artefacts consist of flint sickle blades and perforators and both flint and obsidian cores and blades, preparation pieces and flakes. In addition there were two fragments of an obsidian pendant or link and some thicker pieces of obsidian, possibly core ends which have been chipped and partially ground (Figure 9).

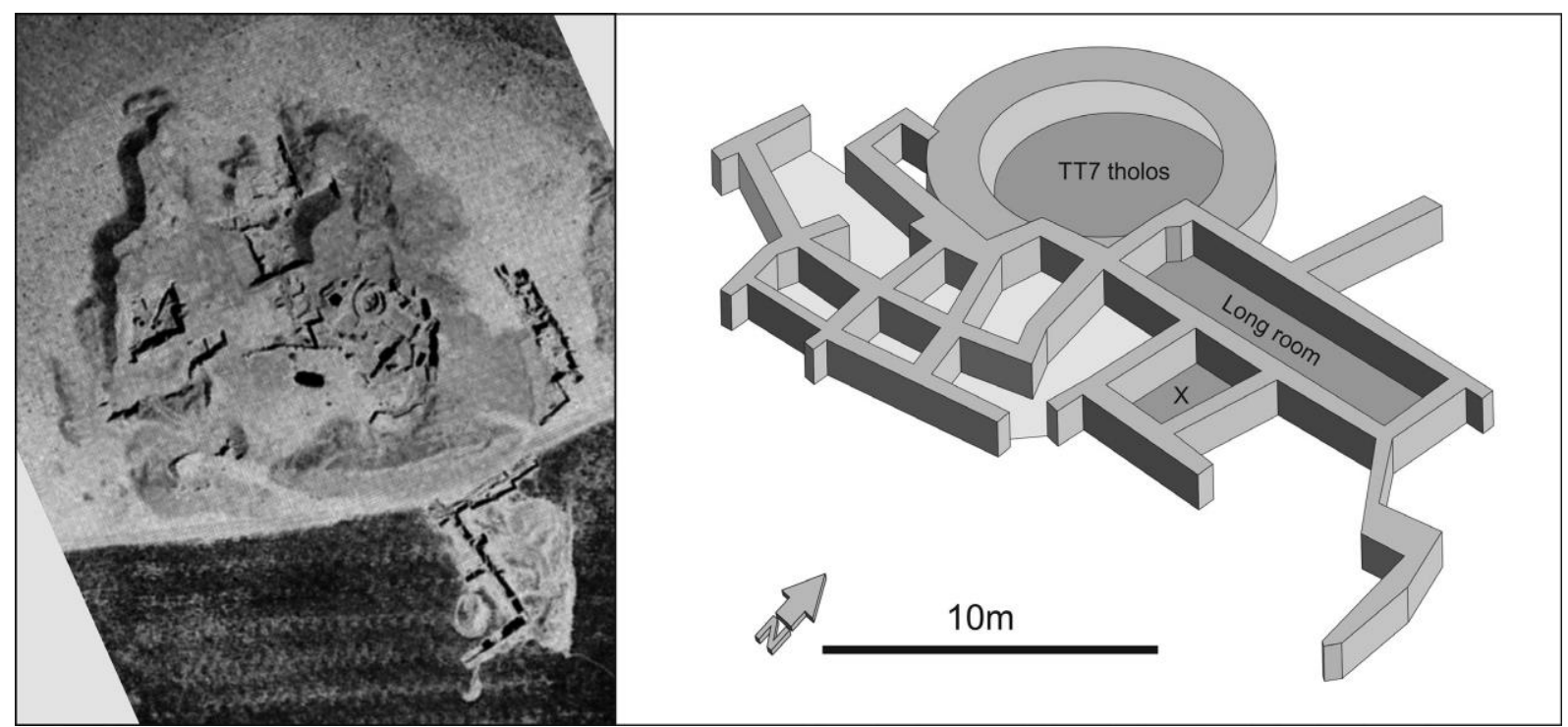

Figure 6. Left: air photograph of Arpachiyah during excavation; the TT7 tholos underlying the Burnt House is visible at the centre right (RAF photo. Original in British Museum). Right: isometric reconstruction of the TT6 Burnt House indicating the long room where most of the obsidian was found.

After the excavation the artefacts were divided between the expedition and the Iraq Museum in Baghdad. The finest pieces from the expedition share were given to the British Museum with other items distributed to various museums around the world. The necklace and seventeen of the links ended up in the British Museum and the bulk of the lithic debitage in the Institute of Archaeology, UCL, London, including two small broken perforated, ground and polished pieces and some sub-discoidal partially ground pieces (Figure 9); the remaining links and the vessel are in the Iraq Museum which were fortuitously recorded as part of another project by Campbell in the 1980s (Campbell 2000). 


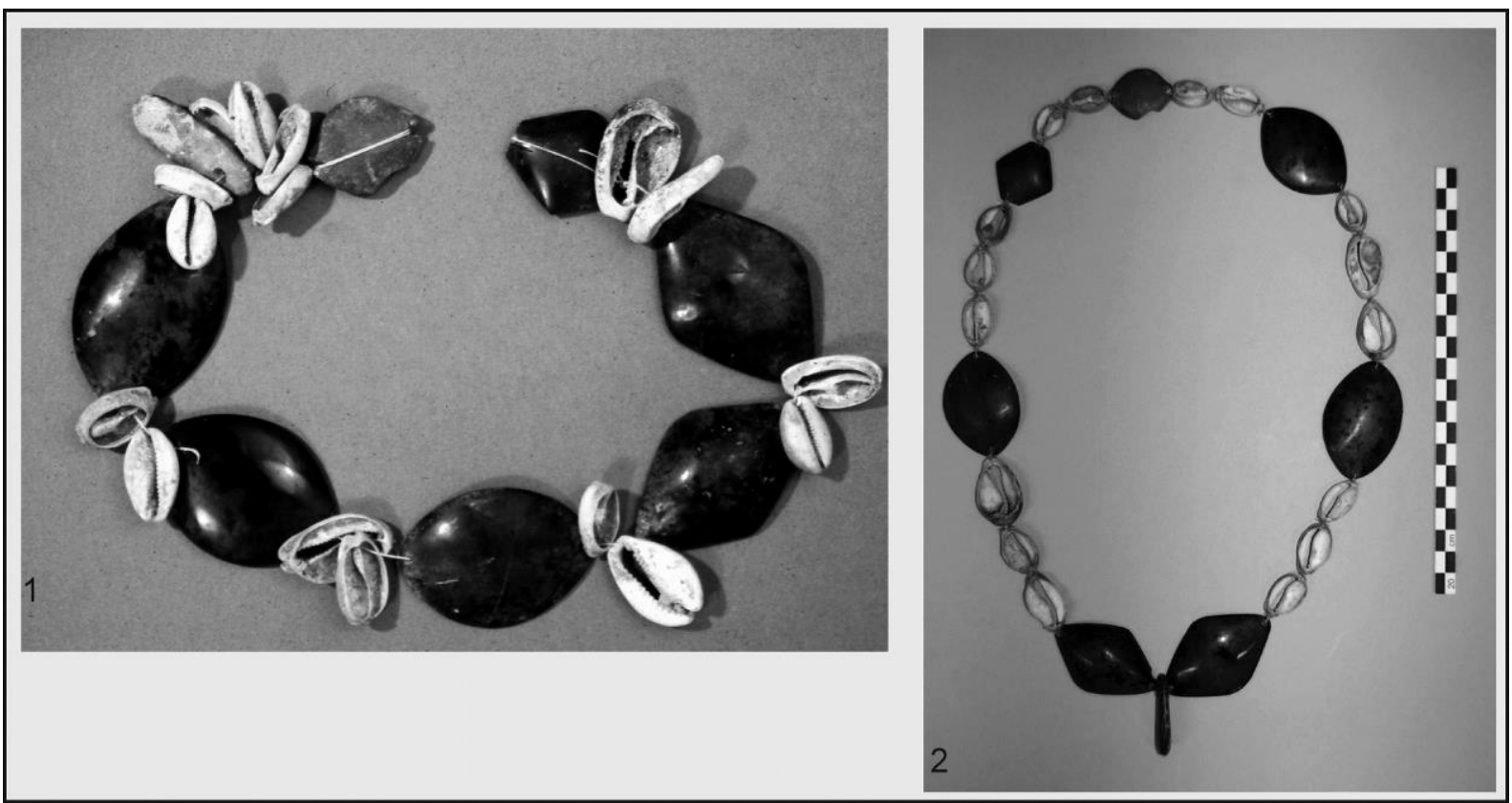

Figure 7. The necklace from Arpachiyah (A909): note the obsidian links interspersed with cowrie shells, stone pendant and clay bead. (1) as strung in the 1980s, (2) as currently strung and possibly found (@Trustees of the British Museum).

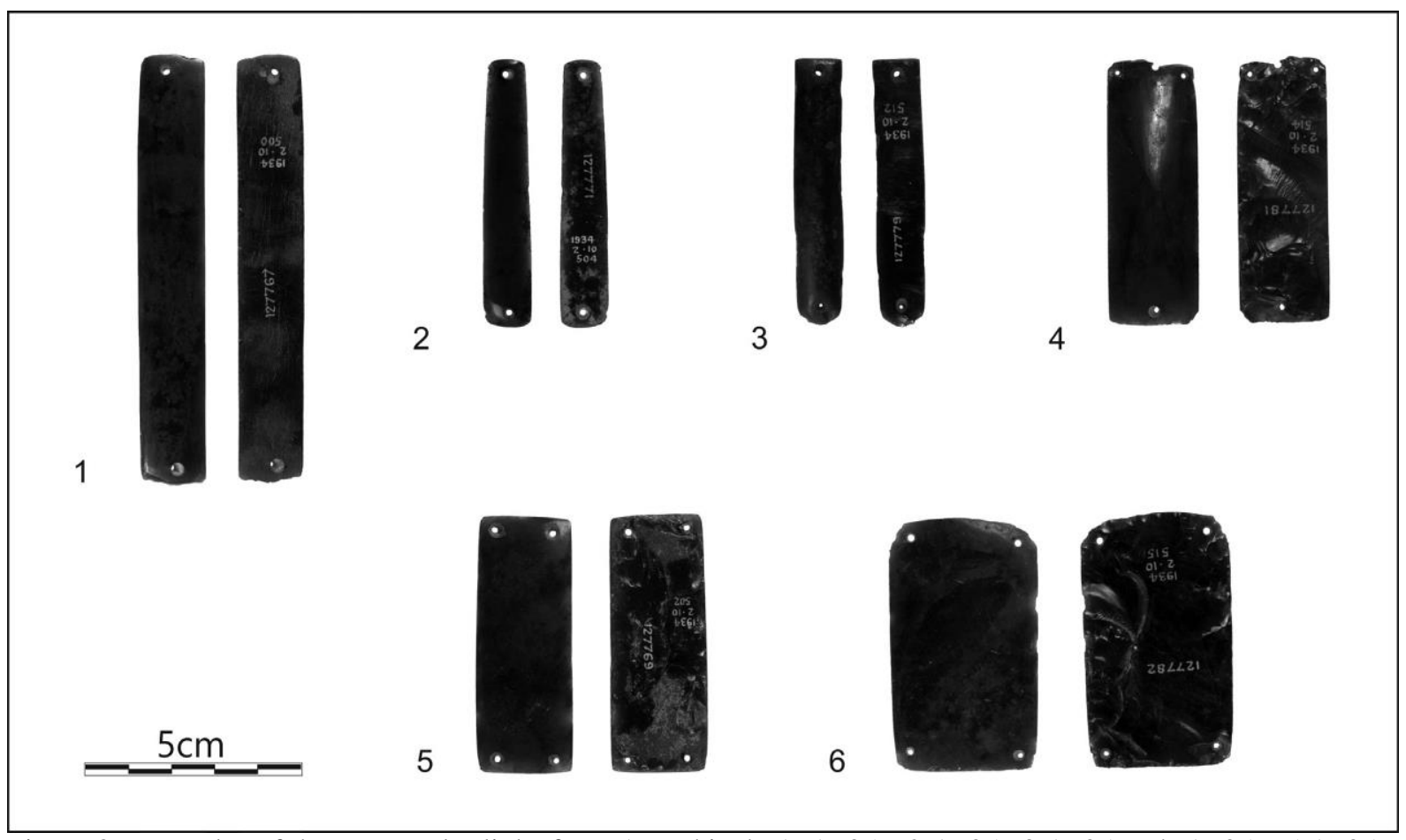

Figure 8. Examples of the rectangular links from Arpachiyah. 1: A905a, 2:A905e 3:A905m, 4: A905o, 5:A905c, 6: A905p (photographs by Stuart Campbell).

The presence of a range of highly finished, elaborate and sometimes exotic objects of various types, together with stone tools and chipped stone debitage, in such a prominent structure as the Burnt House, suggests that the location and association of the objects was of some importance and certainly very different from most other contexts in which obsidian has been found. We felt that an in-depth study of the obsidian objects, made of an unequivocally imported material, could help determine the function of the Burnt House. Our aim was to try to determine whether the links could have been made in the Burnt House or indeed were the 
result of a single episode of manufacture there or elsewhere, and to see whether the debitage recorded by Mallowan could be implicated in their manufacture. To achieve this we set up a project to investigate the processes that might have been involved in the manufacture of the links and the origin of the obsidians used, and to compare this with the rest of the obsidian found in the Burnt House (see also Campbell \& Healey 2013).

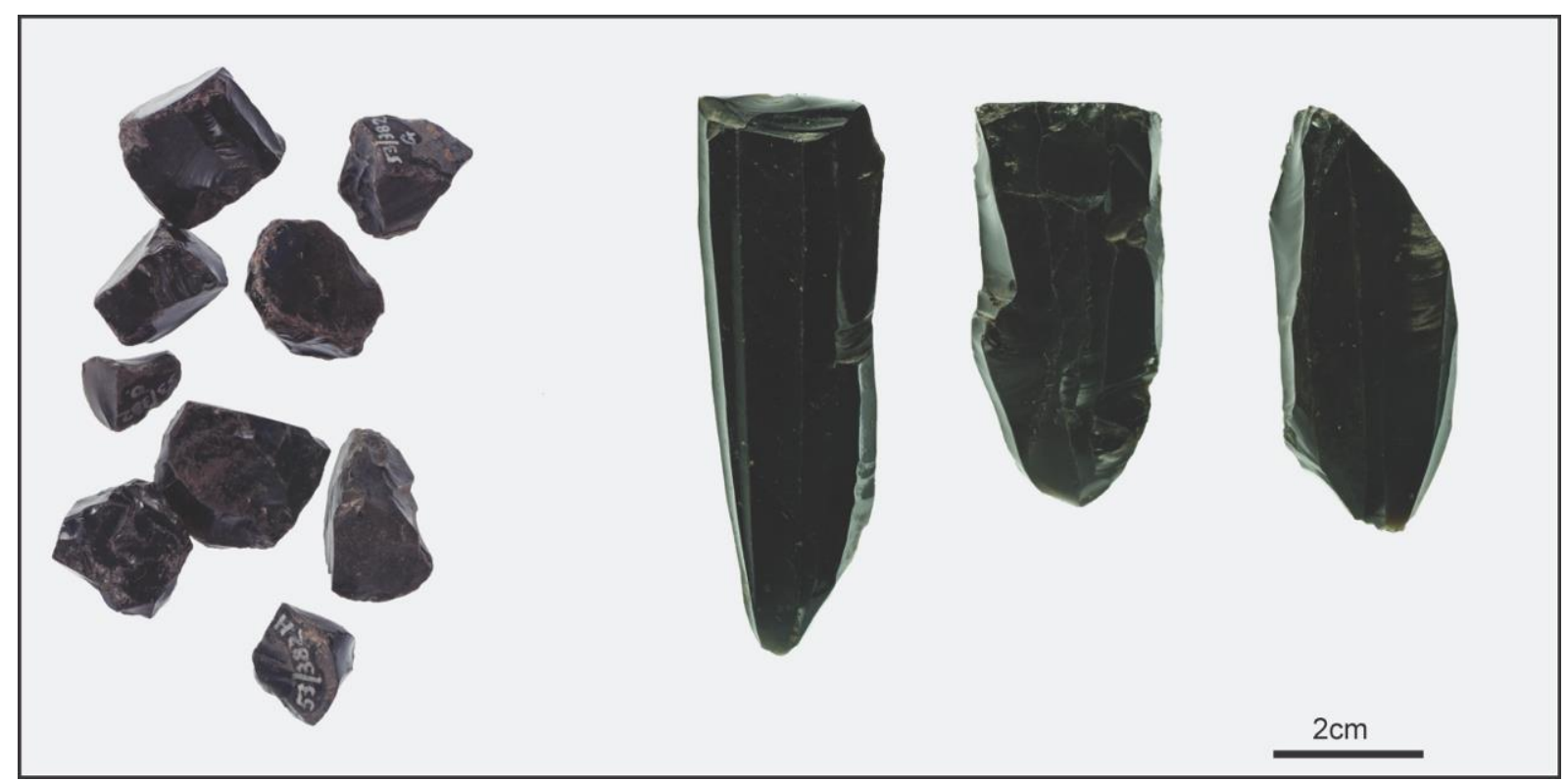

Figure 9. Cores and partially ground chunks from Arpachiyah (photographs by Stuart Campbell).

Previous examination of the obsidian for different purposes suggested that a number of different types were present (Campbell 1992; Healey 2000) but the only provenance analysis then available was that carried out by Renfrew in 1960s on five, now unidentified, pieces of obsidian (Renfrew et al. 1966). This indicated that both obsidian from his group 4c (Bingöl A/Nemrut Dağ), Bingöl B and an unknown source was present. Since then others have geochemically analysed other artefacts in Australian and Canadian museums: five in Australia have been attributed to Meydan Dağ and Bingöl B and two in Canada are from Meydan Dağ (Forster \& Grave 2012; personal communications with Tristan Carter). We were fortunate in obtaining permission from the British Museum and funding from the British Academy and CHARISMA to analyse the links and other artefacts at the AGLAE facility in the Louvre using PIXE. This enabled us to geochemically characterize 22 links (all those in the British Museum) and 51 other pieces, mostly debitage but also two fragments of a pendant or small link in the Institute of Archaeology and two of the partly ground pieces. The results of the analyses showed that all the links in the necklace were made of peralkaline obsidian from a single flow on Nemrut Dağ (probably Frahm's flow EA21/22 (Frahm 2010)) as were 13 of the rectangular links and the small partly ground pieces; a further two of the rectangular links were made of calcalkaline obsidian from the Bingöl area and another three of obsidian probably from Meydan Dağ. The flakes, blades and cores showed similar origins. This data, together with correlation of colour with source (Healey \& Campbell 2009; see also Milič et al. 2013), allowed us to attribute the bulk of the debitage to different sources with a reasonable degree of confidence. The green obsidian comes from a peralkaline source, almost certainly Nemrut Dağ, although the possibility that some are from the Bingöl A group cannot be ruled out. The grey and black obsidian probably originates from the Bingöl B group, Meydan Dağ or both. In essence this means that about $75 \%$ of the debitage originated from Nemrut Dağ (with the possibility that some came from Bingöl A sources) and the bulk of the remaining $25 \%$ of the debitage came from the calcalkaline sources of Bingöl and Meydan Dağ. A few 
completely colourless flakes are from an unknown source (Campbell \& Healey 2013; Campbell et al. in preparation). In terms of the origins of the obsidian, the debitage could be compatible with the manufacture of the links.

Our interpretation of the manufacturing processes are necessarily based on inferences from the observation of finished pieces since no. unfinished links or tools which could be associated with their manufacture are present among the debitage. However, we may note the presence of three stylised objects of pumice and another of sandstone in the Burnt House (Mallowan \& Rose 1935: 100 and Pl. X, d-f; Campbell 2000: 20, Fig. 13.1), which perhaps indicates the presence of material that could have been used for grinding.

The links themselves are of standardised sizes and shapes (Figure 10), suggesting that blanks (blades and flakes) of a particular type must have been chosen. The larger of the oval and lozenge shaped links measure between 53 and $60 \mathrm{~mm}$ in length and 30-37 mm in width and 7-9.7 $\mathrm{mm}$ in thickness. They seem to have been made on large flakes which, allowing for removal of the bulb and about 2 or $3 \mathrm{~mm}$ from the edges to ensure even thickness, we estimate must have been in the region of 65 x $41 \mathrm{~mm}$. Most of the rectangular links were made on blades, though in a few cases the width and the faint evidence of dorsal scarring patterns suggest that the blanks were more likely to have been flakes We estimate that to achieve a typical rectangular link of $60 \mathrm{~mm} \times 15 \mathrm{~mm}$ x $5 \mathrm{~mm}$, a blade measuring about 70-75 x $21 \times 5 \mathrm{~mm}$ would have been needed; this would allow about $5 \mathrm{~mm}$ at each end for the removal of the bulb and regularizing the shape of the distal end, and $3 \mathrm{~mm}$ from the edges to ensure an even thickness (Figure 11). These are sizable blades and flakes and it is likely that they were especially produced as blanks for the links; the most regular blades almost certainly involved reduction by pressure perhaps using the lever technique (Pelegrin 2012).

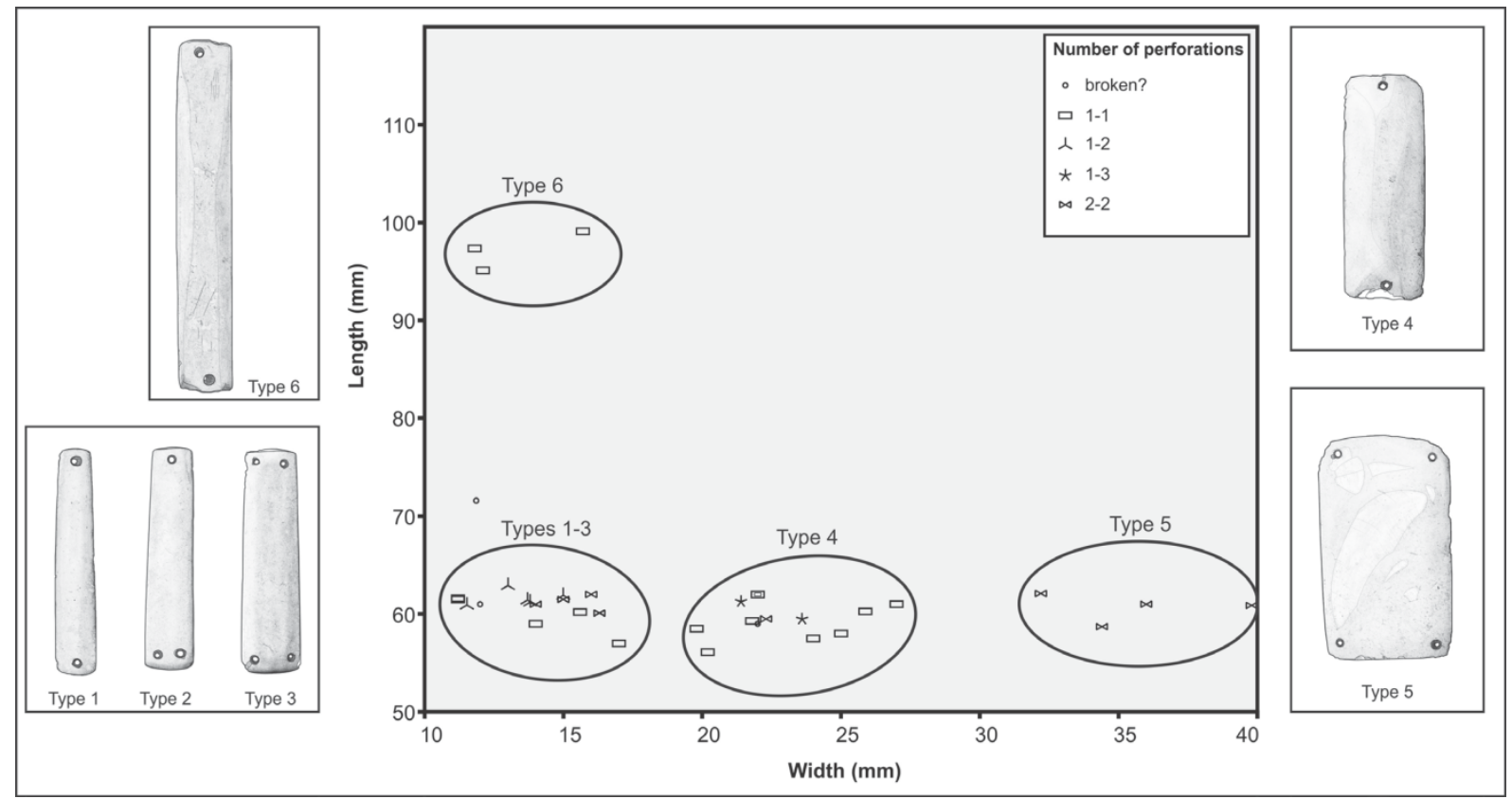

Figure 10. Typology of the rectangular links from Arpachiyah (source Stuart Campbell).

Once a suitable blank had been selected the ends and edges were worked (probably by flaking or retouch) into a symmetric, rectangular shape of relatively standard size, the ends were ground to shape (some are bevelled suggesting that they may have been closely abutted but that they would have articulated without rubbing against each other) and attention was given to the ventral surface. It is sometimes left unmodified but at other times prepared by grinding or flaking. After this the sides were regularized by grinding, which in most cases is quite coarse; it was executed in a longitudinal motion, sometimes leaving spalling along the 
ventral surface. In a few instances the flaking of the ventral surface is extensive and appears to have taken place after the grinding of the sides and possibly indicates reworking. The next stage seems to have been to grind down the dorsal surface of the blanks to obliterate the ridges and to form an even, regular dome-shape thus creating a plano-convex section; the link was then ready for perforating prior to the final polishing. We surmise that this was the order because most links show chipping and signs of drill slippage on the ground surface. The links were transversally perforated from each side with varying degrees of success as there are some mis-drillings. Judging by the regular striations in the holes, this was probably achieved using a bow or other sort of mechanical drill (Gwinnet \& Gorelik 1981; Bains et al. 2013). Sometimes the upper and lower holes are drilled from opposing angles and this may indicate that the hole at each end was initiated from different faces (as the unfinished link at Domuztepe, Figure 3, no.12). The final stage was the polishing the dorsal surface of the links to create a highly reflective surface but few now retain this level of polish probably due to post-depositional factors. We hope that our observations on the processes and stages of manufacture will be corroborated by the experimental replication of the links currently being undertaken by Laurence Astruc, Athina Boletti and tribological analysis by Roberto Varioglu (CNRS); hopefully this will also identify the nature of the materials need to achieve the various levels of finish as well as the methods used and the sorts of skills needed and the time involved in their manufacture.

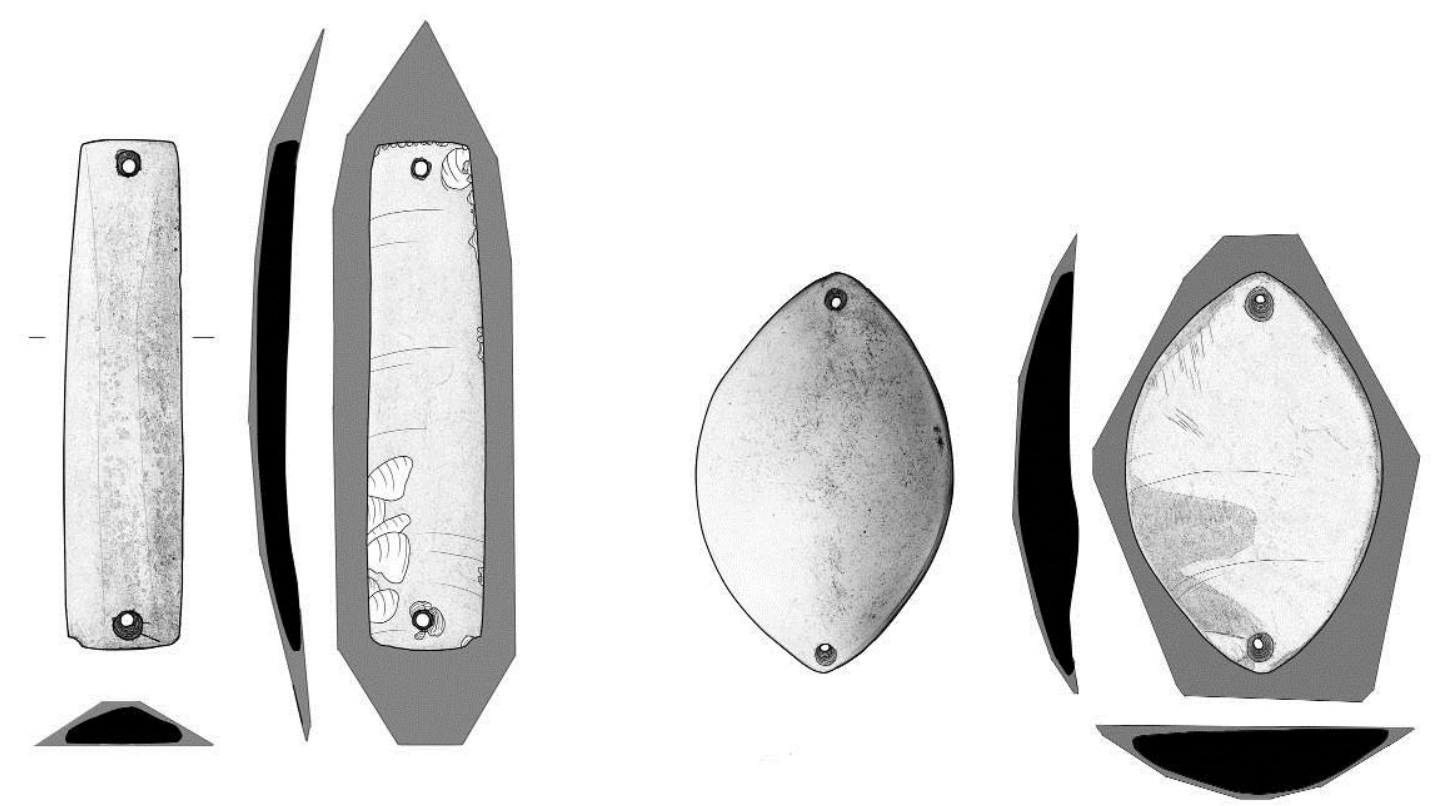

Figure 11. Schematic diagram to indicate the size of the original blade or flake that likely would have been needed to make a rectangular link, A905g 60.7 x 15.5 × $3.5 \mathrm{~mm}$ and an oval link A909j 51.7 × $36,1 \times 7.8 \mathrm{~mm}$ (source Elizabeth Healey; drawing of links S. Bellshaw).

Although the links appear quite standard in their size, shape and manufacturing method, there are a number of subtle differences, such as the different methods and levels of care in making the perforations and in the degree of grinding. We also noted differences in the links made of non-peralkaline obsidian. For example A905c (Figure 8, no. 5) is made of obsidian from Bingöl B or Meydan Dağ and is unique in having its ventral surface ground and then flaked and A905m (Figure 8, no. 3) also of calcalkaline obsidian, has differently shaped terminations and the proximal end of the blade blank has not been truncated to the same extent as the others so that the perforation goes through the thickness of the bulb. 
As well as these slight differences in manufacture, we noted that some of the links had different signs of wear, including some that were re-perforated when the hole broke either side of the broken hole to maintain the length of the link (Figure 8, no. 4, A905o). Some are re-flaked on the ventral surface after edge grinding (Figure 8, nos. 4 and 6, A905o and p). A different solution to the 'repair' of a broken hole is seen on the small lozenge-shaped obsidian link in the necklace where the edge of the broken perforation was ground smooth, necessitating a different way of stringing the link. It is tempting to see the clay bead of almost the same size and also broken across the perforation as an imitation of this. These and other attributes suggest to us that the links had had different and extended life-histories starting from the selection of the blank and were not freshly made for the group as found.

Despite this we felt that it was important to examine the debitage to see if it could have something to do with the manufacture of the links. Certainly the collection of so much obsidian debitage in one place is unusual and, in an assemblage that in other respects is composed of finished items, it seems that it may have been deliberately placed. Therefore, we examined the over 2000 obsidian artefacts that survive in the Institute of Archaeology, London which, as far as we can reasonably ascertain, come from the Burnt House to see if, even theoretically, it could have been connected with the manufacture of some or all of the links even if some had been brought together from different places. To this end we recorded techno-typological attributes, dimensions and other physical characteristics including colour in transmitted light. They are summarized by obsidian type in Figure 12.

It is clear from this study that there are a few blades and flakes present which would have been large enough to serve as blanks for the links, suggesting that cores potentially large enough to produce suitable blades had been available. However, the surviving cores are thoroughly reduced and the debitage much smaller. Some, too, are retouched or show evidence of use. It is of course probable that we only have a partial or mixed assemblage. On balance, though, it seems unlikely that the debitage relates immediately to their manufacture. Its inclusion in the Burnt House may, however, be significant and embody meaning of activities going on there (for related discussion see Carter 2007).

\section{The wider picture}

Obsidian is regularly used in contemporary sites as an exotic raw material (Healey 2000; 2007: Table 2). Amounts range from very small amounts to quantities as large as, or 'more common than' flint. The latter situation is particularly common in northern Iraq and northeast Syria, including the region in which Arpachiyah is located. In some assemblages there is evidence for core reduction and tool production; in others obsidian seems to be present only in the form of blades, with no evidence of core reduction on site. The obsidian used in the northern Mesopotamian sites is mainly from Nemrut Dăg and Bingöl B sources, but occasionally we note the presence of Meydan Dağ. Further to the west, obsidians from both south east Anatolian and Cappadocian sources are present and we may note that both Tell Kurdu and Domuztepe have obsidian from Sarıamıs. This provides only a very general picture because it is often hard to tease out exact amounts or technological information from published data and few assemblages have provenance data (Healey 2000: Appendix 5). Some (in fact an estimated $35-40 \%$ based on present evidence) of these assemblages also have ground and polished items of obsidian but of different forms and finishes (Table 1); evidence for their manufacture or even repair, however, is all but absent, repairs being noted only at Domuztepe, Arpachiyah and Kazane Höyük (see below). For this reason we focus here more on the presence and morphology and finish of the ground and polished obsidian artefacts and on any potential evidence for their manufacture. 

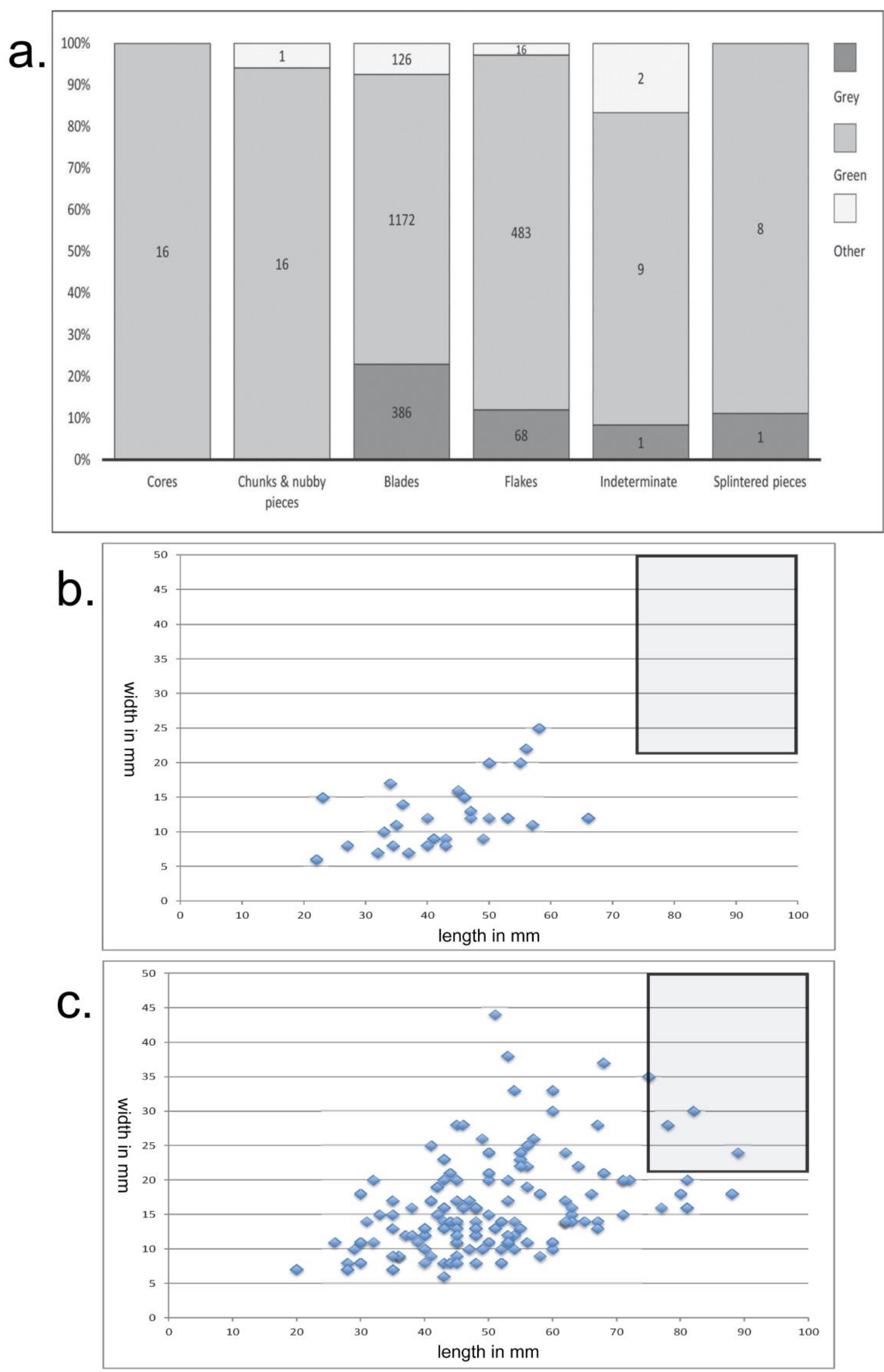

Figure 12. Charts summarizing the obsidian debitage from Arpachiyah currently in the Institute of Archaeology in London: a. by type and colour. b. \& c. scattergram showing the length and width of complete grey and green blades; inset rectangles show estimated size of blank required to make rectangular links (b. obsidian, c. green obsidian) (source Stuart Campbell and Elizabeth Healey). 
Table 1. The occurrence of ground and polished obsidian at selected sites within the Halaf area of influence broadly contemporary with Late Halaf levels at Domuztepe and Arpachiyah (note there is considerable variation in the amount of information available). For further details see Healey 2007, Table 2.

\begin{tabular}{|c|c|c|c|c|c|c|c|c|}
\hline \multirow[b]{2}{*}{ 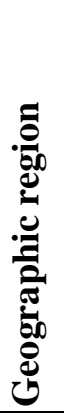 } & \multirow[b]{2}{*}{$\stackrel{\oplus}{\dot{n}}$} & \multicolumn{2}{|c|}{$\begin{array}{l}\text { Origin of } \\
\text { obsidian }\end{array}$} & \multirow[b]{2}{*}{ 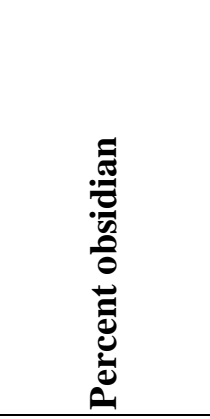 } & \multirow[b]{2}{*}{ 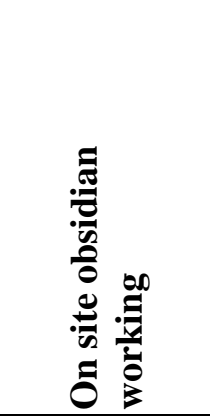 } & \multicolumn{3}{|c|}{$\begin{array}{c}\text { Ground and } \\
\text { polished objects }\end{array}$} \\
\hline & & 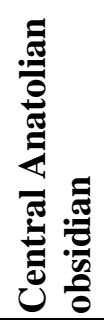 & 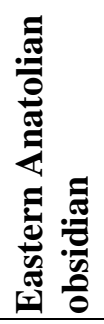 & & & 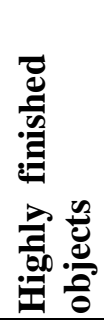 & 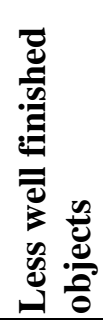 & 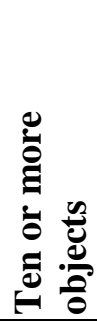 \\
\hline \multirow{5}{*}{$\begin{array}{l}\vec{\Xi} \\
\stackrel{\Xi}{\Xi} \\
.\end{array}$} & Domuztepe & $*$ & $*$ & $9-20 \%$ & $\mathrm{y}$ & $*$ & $*$ & $\mathrm{y}$ \\
\hline & Kurdu & $*$ & $*$ & & $\mathrm{y}$ & & $*$ & \\
\hline & Ras Shamra Vc-IVa & $*$ & & $10-15 \%$ & & $*$ & & \\
\hline & Kabri & & $*$ & not recorded & $\begin{array}{l}\text { very large } \\
\text { core }\end{array}$ & $*$ & & \\
\hline & Hagoshrim & $*$ & $*$ & ratio of $1: 47$ & $\begin{array}{l}\mathrm{y} \text {; also large } \\
\text { core }\end{array}$ & $*$ & $*$ & $\mathrm{y}$ \\
\hline \multirow{6}{*}{ 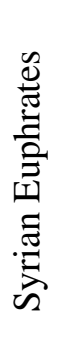 } & Kazane Hoyuk & $?$ & $?$ & $3 \%$ & & $*$ & & \\
\hline & Sabi Abyad Halaf & & $*$ & $22 \%$ & & $*$ & & \\
\hline & Aqab & & $?$ & $80 \%$ & $\mathrm{y}$ & $*$ & & $\mathrm{y}$ \\
\hline & Chagar Bazar & & $*$ & & $\mathrm{y}$ & $*$ & & \\
\hline & Umm Qseir & & $*$ & $36 \%$ & $\mathrm{n}$ & $*$ & & \\
\hline & Tell Halaf & & $*$ & $\begin{array}{c}* \text { (great } \\
\text { quantity) }\end{array}$ & $\begin{array}{l}\mathrm{y} ; \text { also very } \\
\text { large core }\end{array}$ & & $*$ & \\
\hline \multirow{6}{*}{ 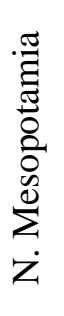 } & Tell Arpachiyah & & $*$ & $50 \%$ plus & $\mathrm{y}$ & $*$ & & $\mathrm{y}$ \\
\hline & Tepe Gawra & & $?$ & & & $*$ & & \\
\hline & Yarim Tepe II & & $*$ & $20-25 \%$ & & $*$ & & \\
\hline & Yarim Tepe III & & $*$ & numerous & & $*$ & & \\
\hline & Banahilk & & $*$ & $29 \%$ & $\mathrm{y}$ & $*$ & & \\
\hline & Nineveh & & $?$ & much & $?$ & $*$ & & \\
\hline
\end{tabular}

Ground and polished items are also found outside of the region which is normally understood as the traditional sphere of Halaf influence in southern Mesopotamia and the Gulf at about this time.

Distinctive rectangular links like those from Arpachiyah have been reported from only two other sites, both in northern Mesopotamia, namely Tepe Gawra XVI where a link $60 \mathrm{~mm}$ long and $20 \mathrm{~mm}$ wide was recorded (Tobler 1950; Pl. CLXXV, no. 71) and a fragmentary one from Banahilk (15 mm wide and $35 \mathrm{~mm}$ plus in length (Watson 1983: 573, Fig. 210.4)). Another possible example measuring $15 \mathrm{~mm}$ in width was found in late Halaf levels at Kazane in SE Anatolia described as a "very thin elongated oblong made of ground and polished obsidian with bevelled edges and two holes at one end" (Bernbeck et al. 1999: 124, Fig. 17c). It appears to have broken across one of the holes and been re-pierced beneath the hole unlike the Arpachiyah ones which are re-pierced beside the broken hole. There are also several related examples in the British Museum from Chagar Bazar but inspection suggests that they are not quite the same as those from Arpachiyah in that one edge is thicker than the other; they are made of calcalkaline obsidian of Bingöl B type (Campbell et al. in 
preparation). It appears that we are dealing with several different types of objects, the most similar being found at settlements which lie within as short distance (c. $40-50 \mathrm{~km}$ ) of each other, suggesting localised traditions.

Oval and lozenge-shaped links of the type in the Arpachiyah necklace have been recorded from at least seven sites, notably Tell Aqab (where they are found in considerable numbers and described as being "exactly like those from the necklace at Arpachiyah" although they are not illustrated and no dimensions are given (Davidson \& Watkins 1981: 10)), Tepe Gawra where they are a little smaller and one is perforated at four points (Tobler 1950: Pl. XCII, c3), Yarim Tepe III (53 x $34 \mathrm{~mm}$ and a smaller oval one 40 x $22 \mathrm{~mm}$ (Merpert \& Munchaev 1993a: 178, Fig. 9.23)), Banahilk (although seemingly a little smaller it is possibly of green obsidian (Watson 1963: 576-77 \& Fig. 264)), Ras Shamra (50 x 35 mm (de Contenson 1992: 108, Pl. XCVIII, 5)), Choga Mami (Mortensen 1973: 37-55) and possibly Chagar Bazar though again this is a little small and not certainly pierced at both ends (Mallowan 1936: 24, Fig 7, 30).

Other elaborate types include incised pendants which have been recovered from Domuztepe, Chagar Bazar and possibly Umm Qseir (Cruells 2006: 44, Pl. 4.1b) and Tepe Gawra XVI (Tobler 1950: Pl. CLXXII, 22 \& 29).

Beads of obsidian occur at most sites, sometimes highly finished like the barrel-shaped beads from Ras Shamra IVA (de Contenson 1992: 115, Pl. CIII, 4), Tepe Gawra (Tobler 1950: Pl. XC, a) and Yarim Tepe II (Merpert \& Munchaev 1993b: 216, Fig. 10.7.1 \& 2). Small irregular disc beads also occur at Tepe Gawra (Tobler 1950: Pl. XCb) and Yarim Tepe II (Merpert \& Munchaev 1993b: Fig. 10.7.2). Unground beads have been found at the contemporary site of Hagoshrim in the southern Levant (Schechter et al. 2013: 522, Fig. 11a) suggesting ad hoc production. No workshops dedicated to bead manufacture are known at this time, although they do occur earlier for production in other materials, for example in AzraqJilat basin (Wright \& Garrard 2003) and Kumartepe (Grace \& Calley 1988)).

Other items of personal adornment such as small links and pendants also show different degrees of finish. For example an oval link found in an Amuq C context at Tell Kurdu shows only rudimentary shaping and no grinding (Healey 2004: 13.9), as do those from Tell Halaf (von Oppenheim \& Schmidt 1943: 114, Pl. XXXVII, 3 \& 4, Pl. CXIII, 3 \& 4) where there are also two possible preforms, described as scrapers (von Oppenheim \& Schmidt 1943: 108 \& Pl. XXXIV, $19 \& 20$ ). Others have some grinding as at Hagoshrim which Schechter et al. (2013: 522, Fig. 11 b) consider to be products of a different chaîne opératoire from the beads but they are not as highly finished as some from Domuztepe. Triangular links seem to be a north-eastern Mesopotamian type, recorded from Banahilk (Watson 1983: Fig. 2, 10.5), Tepe Gawra (Tobler 1950: Pl. CLXXV \& Fig. 69) and Yarim Tepe III (Merpert \& Munchaev 1993a: 240, Fig. 11.10.12).

Although neither vessels nor mirrors have been discussed in this paper, it is worth noting that that they are part of the repertoire of ground and polished items of obsidian in 6th millennium cal. BC northern Mesopotamia and that the non-utilitarian use of obsidian is not confined to personal adornment. Again we can note two different types of finish. Most vessels are thinned walled and highly polished (as those from Domuztepe Figure 3, no. 6, and Banahilk (Watson 1983: 574)); thicker but highly polished and incised are also known from Hagoshrim in the southern Levant (Schechter et al. 2013: Fig. 11d \& e). Unpolished examples, shaped by pecking and sometimes grinding, are present at both Domuztepe (Figure 3, no. 5) and Arpachiyah. Similarly 'mirrors' are of different types and finish from elaborate to simple forms 


\section{Conclusions}

The array of different types and degrees of finish of ground and polished artefacts from basic to highly finished suggests that they belonged to different contexts and perhaps involved different concepts of manufacture (although the operational sequences may have been similar). Special targeted blanks may have been produced for the highly polished links like those from Arpachiyah, whereas elsewhere there may have been more opportunistic use of general debitage.

At Domuztepe we see some localized and small-scale production of certain objects which in the initial stages at least seem to part of the continuum or even a spin-off from tool production. It may well be that the less elaborate pieces from other sites were also locally made, perhaps in similar circumstances. In all cases there is evidence of obsidian working on site so the opportunity for parallel but linked production existed. The more elaborate and standardized objects such as the vessels, mirrors with strap-handles as well as links like those from Arpachiyah seem to be products which require a different mindset and higher levels of expertise to produce them (compare different levels of bead making expertise in Khambhat (Bril et al. 2005: 67ff; Roux \& David 2005)). The accumulation of such objects in the Burnt House at Arpachiyah, even if they were not made there, may be indicative of some sort of common product and a centralized system of acquisition and dispersal and perhaps expertise at least in north-eastern Mesopotamia. The challenge now is to understand the organisation and social context of such a system, as well as the mechanisms through which techniques were developed, learnt and practiced, whether in one or in several locations.

\section{Footnote}

1. Whether this is because flint was a local, everyday material and therefore not considered appropriate for jewellery or whether it simply too difficult to work in this way is beyond the scope of this paper. Conversely we may note that at Çatalhöyük where obsidian is the predominant raw material used to make tools, it is not listed amongst the raw materials used to make items of personal adornment although chert is (Bains et al. 2013: Tables 19.1-3; although see Mellart 1964: 95 \& Pl. XXVc). It is of course also use to make mirrors at Çatalhöyük (see, for example, Vedder 2005).

\section{References}

Bains, R., M., V., Bar-Yosef Mayer, D.E., Russell, N., Wright, K.I. \& Doherty, C. 2013, A technological approach to the study of personal ornamentation and social expression at Çatalhöyük. In: Substantive technologies at Çatalhöyük. Reports from the 2000-2008 seasons, (Hodder, I., Ed.), BIAA Monograph No. 48, Monumenta Archaeologica Vol. 31, British Institute at Ankara: Cotsen Institute of Archaeology at UCLA, Los Angeles: p. 331-364.

Belcher, E. 2011, Halaf bead, pendant and seal 'workshops' at Domuztepe: technological and reductive strategies. In: The state of the stone: Terminologies, continuities and contexts in Near Eastern Neolithic lithics, (Healey, E., Campbell, S. \& Maeda, O., Eds.), ex oriente, Berlin: p. 135-143.

Bernbeck, R., Pollock, S. \& Coursey, C. 1999, The Halaf settlement at Kazane Hoyuk: preliminary report on the 1996 and 1997 seasons. Anatolica, 25: 109-147. 
Binder, D. 2008, Technologie lithique et comportement social dans le PPN de Çayönü tepesi (Turquie). Un aperçu à travers l'analyse des matières premières. Paléorient, 34(1): 5-21. (in French) ("Lithic technology and social behaviour in PPN Çayönü Tepesi (Turkey). An overview through the analysis of raw materials") Stable URL: http://www.jstor.org/stable/i40073124

Bril, B., Roux, V. \& Dietrich, G. 2005, Stone knapping: Khambhat (India), a unique opportunity? In: Stone knapping. The necessary conditions for a uniquely Hominin behavior, (Roux, V. \& Bril, B., Eds.), MacDonald Institute for Archaeological Research, Cambridge: p. 53-71.

Calley, S. \& Grace, R. 1988, Technology and function of micro-borers from Kumartepe (Turkey). In: Industries lithiques tracéologie et technologie (Lithic industries: Traceology and Technology) Volume 1. (Beyries, S., Ed.), British Archaeological Reports International series 411(i), Oxford: p. 69-81.

Campbell, S. 2000, The burnt house at Arpachiyah: A Reexamination, Bulletin of the American Schools of Oriental Research, 318: 1-40. doi:10.2307/1357725

Campbell, S. \& Fletcher, A. 2013, Scale and integration in Northern Mesopotamia in the early 6th Millennium cal. BC. In: Interpreting the Late Neolithic of Upper Mesopotamia, (Nieuwenhuyse, O.P., Bernbeck, R., Akkermans, P.M.M.G. \& Rogasch, J., Eds.). Brepols, Turnhout: p. 39-50.

Campbell, S. \& Healey E. in preparation, A re-examination of the obsidian from the Burnt House at Tell Arpachiyah.

Carter, T. 2007, The theatrics of technology: Consuming obsidian in the Early Cycladic burial arena. Archeological Papers of the American Anthropological Association, 17(1): 88107. doi:10.1525/ap3a.2007.17.1.88

Cauvin, M.-C., Gourgaud, A., Gratuze, B., Arnaud, N., Poupeau, G., Poidevin, J.-L. \& Chataigner, C. 1998, L'obsidienne au Proche et Moyen Orient: du volcan à l'outil. British Archaeological Reports International Series 738. Archaeopress, Oxford, 388 p. (in French with English foreword) ("Obsidian in the Near and Middle East: From Volcano to Tool")

de Contenson, H. 1992, Préhistoire de Ras Shamra: Les sondages stratigraphiques de 19551976. Editions récherche sur les civilisations, Paris. (in French) ("The prehistory of Ras Shamra: Stratigraphic surveys from 1955 to 1976”)

Coşkunsu, G. 2008, Hole-making tools of Mezraa Teleilat with special attention to microborers and cylindrical polished drills and bead production. Neo-Lithics 8(1): 25-36.

Costin, C.L. 1991, Craft specialization: issues in defining, documenting, and explaining the organization of production. Archaeological Method and Theory, 3: 31-56.

Stable URL: http://www.jstor.org/stable/20170212

Costin, C.L., Wright, R.P. \& Brumfiel, E.M. 1998, Craft and social identity. Archeological papers of the American Anthropological Association 8(1). doi:10.1525/ap3a.1998.8.1.3

Cruells, W. 2006, Les objets. In: Chagar Bazar (Syrie) 1. Les sondages préhistoriques (Chagar Bazar, Syria. 1. The prehistoric excavations). (1999-2001), (Tunca, Ö, Baghdo, A. \& Cruells, W., Eds.), Publications de la Mission archéologiques de l'Université de Liège en Syrie, Peeters, Louvain: p. 81-94. (in French) (“The objects") 
Davidson, T.E. \& Watkins, T. 1981, Two seasons of excavations at Tell Aqab in the Jezirah, northeast Syria. Iraq, 43: 1-18. Stable URL: http://www.jstor.org/stable/4200130

Forster, N. \& Grave, P. 2012, Non-destructive PXRF analysis of museum-curated obsidian from the Near East. Journal of Archaeological Science, 39(3): 728-736. doi: $10.1016 /$ j.jas.2011.11.004

Frahm, E. 2010, The Bronze-Age obsidian industry at Tell Mozan (Ancient Urkesh), Syria: Redeveloping electron microprobe analysis for 21 st-century sourcing research and the implications for obsidian use and exchange in Northern Mesopotamia after the Neolithic, PhD. Thesis , Department of Anthropology, University of Minnesota-Twin Cities, Minnesota, 1019 p.

Frahm, E., Campbell, S. \& Healey, E. in preparation, Characterisation of the obsidians from Domuztepe.

Grace, R. 1990, The use-wear analysis of drill bits from Kumartepe. Anatolica 16: 154-155.

Gwinnett, A. J. \& Gorelick, L. 1981, Beadmaking in Iran in the Early Bronze Age derived by scanning electron microscopy. Expedition 24(1): 10-23.

Healey, E. 2000, The role of obsidian in the Late Halaf, $\mathrm{PhD}$. Thesis, University of Manchester, Manchester.

Healey, E. 2004, The Tell Kurdu 2001 Chipped stone. In: Tell Kurdu Excavations 2001, (Özbal, R., Gerritsen, F., Diebold, B., Healey, E., Aydın, N., Loyet, M., Nardulli, F., Reese, D., Ekstrom, H., Sholts, S., Mekel-Bobrov, N. \& Lahn, B (2004)), Anatolica 30: 56-60.

Healey, E. 2007, Obsidian as an indicator of inter-regional contacts and exchange: three casestudies from the Halaf period. Anatolian Studies 57:171-189.

Stable URL: http://www.jstor.org/stable/20455402

Healey, E. 2013, Exotic, aesthetic and powerful? The non-tool use of obsidian in the later Neolithic of the Near East. In: Interpreting the Late Neolithic of Upper Mesopotamia (Nieuwenhuyse, O. P., Bernbeck, R., Akkermans, P. M. M. G. \& Rogash, J., Eds.), Brepols, Turnhout: p. 251-266.

Healey, E. in preparation, The lithics from Domuztepe.

Healey, E. \& Campbell, S. 2009, The challenge of characterising large assemblages of exotic materials: A case study of the obsidian from Domuztepe, SE Turkey. Internet Archaeology, 26. doi: 10.11141/ia.26.20

Hirth, K. G. 2009, Craft production, household diversification, and domestic economy in Prehispanic Mesoamerica. Archeological Papers of The American Anthropological Association, 19(1): 13-32. doi:10.1111/j.1551-8248.2009.01010.x

Lehner, J., Campbell, S. \& Healey, E. in preparation, A pXRF analysis of the obsidian from Domuztepe.

Mallowan, M.E.L. 1936, The excavations at Chagar Bazar, and an archaeological survey of the Habur Region, 1934-35. Iraq, 3: 1-59.

Stable URL: http://www.jstor.org/stable/4241586

Mallowan, M.E.L. nd, Mallowan, Arpachiyah records, Unpublished file. British Museum.

Mallowan, M.E.L. \& Rose, J.C. 1935, Excavations at Tall Arpachiyah, 1933. Iraq, 2: 1-178. doi: $\underline{10.2307 / 4241576}$ 
Mellaart, J. 1964, Excavations at Çatal Hüyük, 1962: Second preliminary report. Anatolian Studies, 13:43-103. Stable URL: http://www.jstor.org/stable/3642490

Merpert, N. \& Munchaev, R. M. 1993a, YarimTepe III: The Halaf levels. In: Early stages in the evolution of Mesopotamian civilization. Soviet excavations in Northern Iraq (Yoffee, N \& Clark J. J., Eds.), The University of Arizona Press, Tucson and London: p. 163-206.

Merpert, N. \& Munchaev R. M. 1993b, Yarim Tepe II: The Halaf levels. In: Early stages in the evolution of Mesopotamian civilization. Soviet excavations in Northern Iraq, (Yoffee N. \& Clark J. J., Eds.), The University of Arizona Press, Tucson and London: p. 128- 162.

Milić, M., Brown, K. \& Carter, T. 2013, Appendix 21.1: A visual characterization of the Çatalhöyük obsidian, In: Substantive technologies at Çatalhöyük, Reports from the 2000-2008 seasons, (Hodder, I., Ed.), British Institute at Anakara Mongraph 48, Momumenta Archaelologica 31, Cotsen Institute of Archaeology Press, Ankara and Los Angeles. CD.

Mortensen, P. 1973, A Sequence of Samarran flint and obsidian tools from Choga Mami. Iraq. 35: 37-55. doi: $10.2307 / 4199950$

Pelegrin, J. 2012, New experimental observations for the characterization of pressure blade production techniques. In: The emergence of pressure blade making from origin to modern experimentation, (Desrosiers, P. M., Ed.), Springer, New York: p. 465-500. doi:10.1007/978-1-4614-2003-3_18

Renfrew, C., Dixon, J.E \& Cann, J.R. 1966, Obsidian and early cultural contact in the Near East. Proceedings of the Prehistoric Society, 32: 30-72.

Roux, V. \& David, E. 2005, Planning abilities as a dynamic perceptual-motor skill: an actualistic study of different levels of expertise involved in stone knapping. In: Stone knapping. The necessary conditions for a uniquely Hominin behaviour, (Roux, V. and Bril, B. Eds.), MacDonald Institute for Archaeological Research, Cambridge: p. 91-108.

Schechter, H., Marder, O., Barkai, R.,Getzov, N. \& Gopher, A. 2013, The obsidian assemblage from Neolithic Hagoshrim, Israel: pressure technology and cultural influence. In: Stone tools in transition: From hunter-gatherers to farming societies in the Near East. (Borrell F., Ibáñez, J.J. \& Molist, M., Eds.), Universitat Autònoma de Barcelona, Servei de Publicacions, Bellaterra (Barcelona): p. 509-528.

Tobler, A.L. 1950, Excavations at Tepe Gawra. Vol. 2. University of Pennsylvania Press, Philadelphia, $260 \mathrm{p}$.

Vedder, J. 2005, The obsidian mirrors of Çatalhoyük, In: Changing materialities at Çatalhöyük: Reports from the 1995-99 seasons (Hodder, I., Ed.): McDonald Institute for Archaeological Research, Cambridge: p. 579-619.

Von Oppenheim, M. \& Schmidt H. 1943, Tell Halaf I: Die prähistorichen Fünde. de Gruyter, Berlin, 140 p. (in German) ("Tell Halaf 1: The Prehistoric Finds")

Watson, P. J. 1983, The soundings at Banahilk. In: Prehistoric archaeology along the Zagros Flanks, (Braidwood, R.B., Braidwood, L., Howe, B., Reed, C.A \& Watson P. J., Eds.), Chicago University Press, Oriental Institute Publication 105, Chicago: p. 545-614. 
White, R. 2007, Systems of personal ornamentation in the early Upper Palaeolithic: methodological challenges and new observations. In: Rethinking the human revolution: New behavioural and biological perspectives on the origin and dispersal of modern humans. (Mellars, P., Ed.), McDonald Institute for Archaeological Research, Cambridge: p. 287-302.

Wright, K. \& Garrard, A. 2003, Social identities and the expansion of stone bead-making in Neolithic Western Asia: New evidence from Jordan. Antiquity, 77 (296): 267-284. 